\title{
Article
}

\section{Determination of Grain Yield Inputs of the Maize Hybrid Giza 168 Using a Six-Factor Central Composite Design in Mediterranean Regions Under Irrigation}

\author{
El-Rouby, M.M. ${ }^{1}$, Omar, M.A. ${ }^{1}$, Nawar, A.I. ${ }^{1}{ }^{*}$, El-Shafei, A.A. ${ }^{2,3}$, Zakaria, O.E. ${ }^{1}$
}

1. Crop Science Dept., Faculty of Agriculture, Alexandria University, Alexandria, 21545, Egypt

2. Agricultural Engineering Dept., College of Food and Agricultural Sciences, Riyadh 11451,

Saudi Arabia

3. Agricultural and Biosystems Engineering Dept., Faculty of Agriculture, Alexandria

University, Alexandria, 21545, Egypt

*Corresponding author: Ali I. Nawar

Email: dralinwar@alexu.edu.eg

Telephone number: +201001620757

ORCID: 0000-0001-6623-8140

\begin{tabular}{|c|c|}
\hline JDEA & $\begin{array}{l}\text { Abstract } \\
\text { The maize single hybrid Giza } 168 \text { was evaluated for grain yield } \\
\text { in a six-factor central composite design in } 2015 \text { and } 2016 \text { summer } \\
\text { seasons. The six factors included; surface irrigation level (I), potassium } \\
(\mathrm{K}) \text {, phosphorus }(\mathrm{P}) \text {, nitrogen }(\mathrm{N}) \text {, sowing date }(\mathrm{SD}) \text {, and plant density } \\
(\mathrm{PD}) \text {. The CROPWAT schedule module was applied for evaluation of } \\
\text { irrigation practices and to develop alternative improved water delivery } \\
\text { schedules. The six studied factors explained } 57 \% \text { of the variation in } \\
\text { grain yield, with significant linear effects for PD }\left(0.48^{*}\right) \text {, I } \times \mathrm{K} \\
\text { interaction }\left(-0.45^{*}\right) \text {, and } \mathrm{P} \times \mathrm{N} \text { interaction }\left(-0.69^{*}\right) \text {. The highest grain } \\
\text { yields }(8.05 \text { and } 8.06 \text { t/ha) were obtained from two combinations, i.e., } \\
\text { high irrigation with high } \mathrm{K} \text {, low } \mathrm{P} \text {, high } \mathrm{N} \text {, late SD, and high PD; and } \\
\text { low irrigation with high } \mathrm{K} \text {, high } \mathrm{P} \text {, low } \mathrm{N} \text {, late SD, and low PD, } \\
\text { respectively. }\end{array}$ \\
\hline Article info. & Simulation of irrigation scheduling indicated that the quantity \\
\hline $\begin{array}{l}\text { Received on:29-11-2020 } \\
\text { Accepted on: } 20-1-2021 \\
\text { Published on: 3-2021 }\end{array}$ & $\begin{array}{l}\text { of irrigation water could be reduced by } 22 \% \text { and the irrigation interval } \\
\text { extended to } 15 \text { days without any loss in grain yield. The results showed } \\
\text { that application of } 270 \mathrm{~kg} \mathrm{~N} / \mathrm{ha}, 100 \mathrm{~kg} \mathrm{~K} 2 \mathrm{O} / \mathrm{ha}, 34.5 \mathrm{~kg} \mathrm{P} 2 \mathrm{O} 5 / \mathrm{ha} \text {, and } \\
\text { sowing at } 20 \text { to } 30 \text { May with a plant density of } 65,000 \text { plants/ha will } \\
\text { realize the highest yield potential of the hybrid Giza } 168 \text {. }\end{array}$ \\
\hline Open Access & $\begin{array}{l}\text { Keywords: Zea mays L., six-factor central composite design, grain } \\
\text { yield, CROPWAT }\end{array}$ \\
\hline
\end{tabular}

Journal of Desert and Environmental Agriculture, 2021. 


\section{Introduction}

Productivity of maize in Mediterranean regions, as in other field crops, is affected by numerous factors; however, agricultural inputs and practices are the main determinants of proper growth and grain yield. These include the choice of a suitable sowing date to provide the plants with ideal environmental conditions for growth and transition from the vegetative to productive stage and to avoid biotic stresses (diseases and insects) at critical growth stages. Differences in sowing dates can greatly affect maize production. For example, Jaliya et al. (2008) and Rah Khosravani et al. (2017) reported that the early sowing in the10th and 15th of June, respectively of maize resulted in higher grain yield as compared to later sowings on 30th June and 1st of July. However, Dahmardeh and Dahmardeh (2010) found that late sowing in August gave higher yields than did early sowing in July. Also, seeding at the appropriate plant density will increase yield by decreasing intra-crop competition and realizing optimum or nearoptimum stand at harvest. Intermediate plant density, ranging from 60,000- 66,000 plants/ha, gave higher grain yield in comparison to lower or higher densities (Turgut et al. 2005; Ramu and Reddy, 2007 and Abuzar et al., 2011). Moreover, the interaction between plant density and nitrogen $(\mathrm{N})$ level plays a main role in maize production. Dahmardeh (2011) and Zakir et al. (2017) reported that, high plant density (66,000-100,000 plants/ha) gave higher grain yield with high $\mathrm{N}$ levels $(300-350 \mathrm{~kg}$ $\mathrm{N} / \mathrm{ha}$ ).

Similarly, water plays an essential role in germination, growth, nutrient and photosynthates translocation, and facilitation of biochemical processes in the plant, and governs pollination and fertilization. Hence, determination of water requirements is necessary to avoid either the drastic effects of drought or excessive irrigation on plant growth and productivity. Several studies have reported that shortening irrigation intervals (higher irrigation levels) resulted in higher grain yields relative to longer irrigation intervals, which can result in drought stress, especially at critical stages of growth such as grain-filling stage (Dahmardeh, 2011; Hammad et al., 2012; Zare et al., 2014 and Ashraf et al., 2016). Interactions between irrigation and $\mathrm{N}$ level have also been reported. Ashraf et al. (2016) reported that the best grain yield was achieved at full irrigation and $250 \mathrm{~kg} \mathrm{~N} / \mathrm{ha}$.

Finally, the nutritional status of the plant has a substantial effect on its growth and productivity. The important roles played by the three macro-elements, i.e., nitrogen $(\mathrm{N})$, phosphorus $(\mathrm{P})$, and potassium $(\mathrm{K})$, in growth, biochemical processes, yield, and quality of maize are well documented; however, rates of application should be determined to avoid deficient or excess application since both cases affect plant growth and productivity and/or have hazardous effects on the environment. Concerning application of macronutrients, Nejad et al. (2010) found that higher K levels (up to $150 \mathrm{~K} 2 \mathrm{O} / \mathrm{ha}$ ) increased grain yield, while Hussain et al. (2007) reported that increasing both $\mathrm{K}$ and $\mathrm{P}$ fertilization levels up to $60-90 \mathrm{~kg} / \mathrm{ha}$ for each, gave the highest grain yield. Moreover, Martineau et al. (2017) found that increasing irrigation with increasing $\mathrm{K}$ fertilization levels gave higher grain yield. With regard to $\mathrm{P}$ fertilization levels, Amanullah and Khalil (2010) and Zhihui et al. (2016) reported that intermediate to high $\mathrm{P}$ levels had favorable effects on grain yield. Similarly, for $\mathrm{N}$ fertilization levels, Hammad et al. (2011), Wang et al. (2014), Zhang et al. (2014), and Ali and Anjum (2017) found that the highest grain yield was obtained with intermediate to high $\mathrm{N}$ application levels. 
Yield is a measure of crop response to changes in levels of applied quantitative factors. Hence, experimental designs could describe yield as a function of the levels of multifactor. Response surface methodology (RSM) is a powerful technique for testing multiple factors using fewer experimental units compared to the study of one variable or combinations of variables, at a time. Also, significant interactions between factors can be identified and quantified by this technique (Cochran and Cox, 1957 and Peterson, 1985).

The objective of this study was to examine the effect of six main factors (irrigation, macro-elements; $\mathrm{N}, \mathrm{P}$ and $\mathrm{K}$ fertilization levels, sowing date and plant density) on grain yield of the hybrid maize cultivar Giza 168 under the Mediterranean conditions in Egypt.

\section{Materials and Methods}

The study was performed at the Agricultural Research Station, Faculty of Agriculture, Alexandria University, Egypt $\left(31^{\circ} 12^{\prime} 53.0^{\prime \prime} \mathrm{N}, 2^{\circ} 59^{\prime} 13.0^{\prime \prime} \mathrm{E}\right)$, during the summer seasons of 2015 and 2016. The cultivar used in both seasons was the maize single hybrid Giza 168 (Giza 658 × Giza 639), developed by the Maize Research Program, Agriculture Research Center, Ministry of Agriculture, Egypt. Before sowing, soil samples were collected from the site (at a depth of $35 \mathrm{~cm}$ from the top soil) to determine the soil chemical and physical properties for the two seasons (Table 1). The meteorological data for the two seasons are presented in Fig. (1). These included minimum and maximum temperatures ( $\square \mathrm{C}$ ), humidity (\%), wind speed $(\mathrm{km} / \mathrm{h})$, sunlight duration (hours), and reference evapotranspiration (ETo) in $\mathrm{mm}$. The data were obtained from the Alexandria-Nouzha Meteorological Station.

Table 1: Soil physical and chemical properties as an average of the two seasons

\begin{tabular}{|l|l|l|c|}
\hline \multicolumn{2}{|c|}{ Physical properties } & \multicolumn{1}{c|}{ Nutritional properties } \\
\hline Clay \% & 62.5 & Av. N $(\%)$ & 0.01 \\
\hline Silt \% & 20.0 & Av. P $(\mathrm{ppm})$ & 9.60 \\
\hline Sand \% & 17.5 & Av. K (meq/L) & 0.84 \\
\hline Texture & Clay & Organic matter $(\%)$ & 0.52 \\
\hline \multicolumn{4}{|c|}{ Chemical properties } \\
\hline pH & $\mathrm{Cl}^{-}(\mathrm{meq} / \mathrm{L})$ & 15.00 \\
\hline $\mathrm{EC}(\mathrm{dS} / \mathrm{m})$ & 8.36 & $\mathrm{CO}_{3}^{-2}(\mathrm{meq} / \mathrm{L})$ & 2.40 \\
\hline $\mathrm{Ca}^{+2}(\mathrm{meq} / \mathrm{L})$ & 7.23 & $\mathrm{HCO}_{3}^{-}(\mathrm{meq} / \mathrm{L})$ & 4.00 \\
\hline $\mathrm{Mg}^{+2}(\mathrm{meq} / \mathrm{L})$ & 4.00 & $\mathrm{SO}_{4}^{-2}(\mathrm{meq} / \mathrm{L})$ & 10.31 \\
\hline $\mathrm{Na}^{+}(\mathrm{meq} / \mathrm{L})$ & 20.21 & $\mathrm{CaCO}_{3}(\%)$ & 9.86 \\
\hline $\mathrm{SAR}^{\mid}$ & & \\
\hline
\end{tabular}


A five-level, six-factor rotatable central composite design, proposed by Box and Wilson (1951), was employed in this study. The design included 32 factorial points (F1-32) resulting from confounding 64 treatments, using the six-factor interaction as defining contrast, 12 central points $(2 \times$ number of factors; $\mathrm{C} 1-12)$, and 12 star points $(2 \times$ number of factors; S1-12) as seen in Table 2 . The total number of experimental units used was 56. The experimental unit area was $28 \mathrm{~m} 2$ (10 ridges each of width $0.7 \mathrm{~m}$ and $4 \mathrm{~m}$ length). Sowing was in hills, on one side of the ridge (the distance between hills for experimental unit varied according to the levels of plant density), and the plants were thinned to one plant/hill 24 days after sowing.

All irrigation levels were applied in nine irrigations (12-day intervals) as surface irrigation. The amount of water applied during each irrigation event varied with the level of irrigation and plant growth stage according to the CROPWAT model. Irrigation was terminated 10 days before harvesting. All $\mathrm{K}$ applications were done in split doses just before the fourth and fifth irrigations after sowing. All $\mathrm{P}$ levels were applied at land preparation. All $\mathrm{N}$ applications were applied in two split doses at 24 days after sowing and at the subsequent irrigation, except $380.8 \mathrm{~kg}$ $\mathrm{N} / \mathrm{ha}$, which was added in three doses (142.8, 142.8 , and $95.2 \mathrm{~kg} \mathrm{~N} / \mathrm{ha}$ ) at 24 days after sowing, and the two subsequent irrigations.

Surface irrigation was applied through a gated pipe system attached with a water meter to measure the amount of water applied. The model of the water meter was TURBO-IR-A DN 80 (3"), manufactured by Bermad Irrigation (Qmin $=6$ $\mathrm{m} 3 / \mathrm{h} \pm 5 \%, \mathrm{Qmax}=150 \mathrm{~m} 3 / \mathrm{h} \pm 2 \%$, and minimum reading unit $=0.01 \mathrm{~m} 3$ ).

Wide borders and deep furrows were used to isolate plots to eliminate any carryover resulting from groundwater levels at different irrigation levels. $\mathrm{P}$ was applied in the form of calcium monophosphate (15.5\% P2O5), while $\mathrm{N}$ was applied in the form of urea $(46.5 \% \mathrm{~N})$ and $\mathrm{K}$ was applied in the form of potassium sulfate $(48 \%$ $\mathrm{K} 2 \mathrm{O}$ ). Experimental units were kept weed-free through hand hoeing at early stages and hand pulling at later stages to eliminate the weed effect.

Grain yield (ton/ha) was determined from the four inner guarded ridges of each plot and transformed to yield/ha. The error of the two years for the characteristics studied was homogenous, as determined by a test of homogeneity of error (Hartley, 1950); hence the data from the two years of study were pooled.

Statistical analysis was carried out according to Peterson (1985). Response surface and contour diagrams for significant linear $x$ linear interactions were performed by STATISTICA 7.0 (StatSoft, 2012), while linear and quadratic responses of main effects were performed by Curve Expert v.1.34 (Hyams, 2005).

Simulation of irrigation scheduling was achieved using CROPWAT (Swennenhuis, 2009) to guarantee efficient water use in the irrigation process and to control surplus water use. 

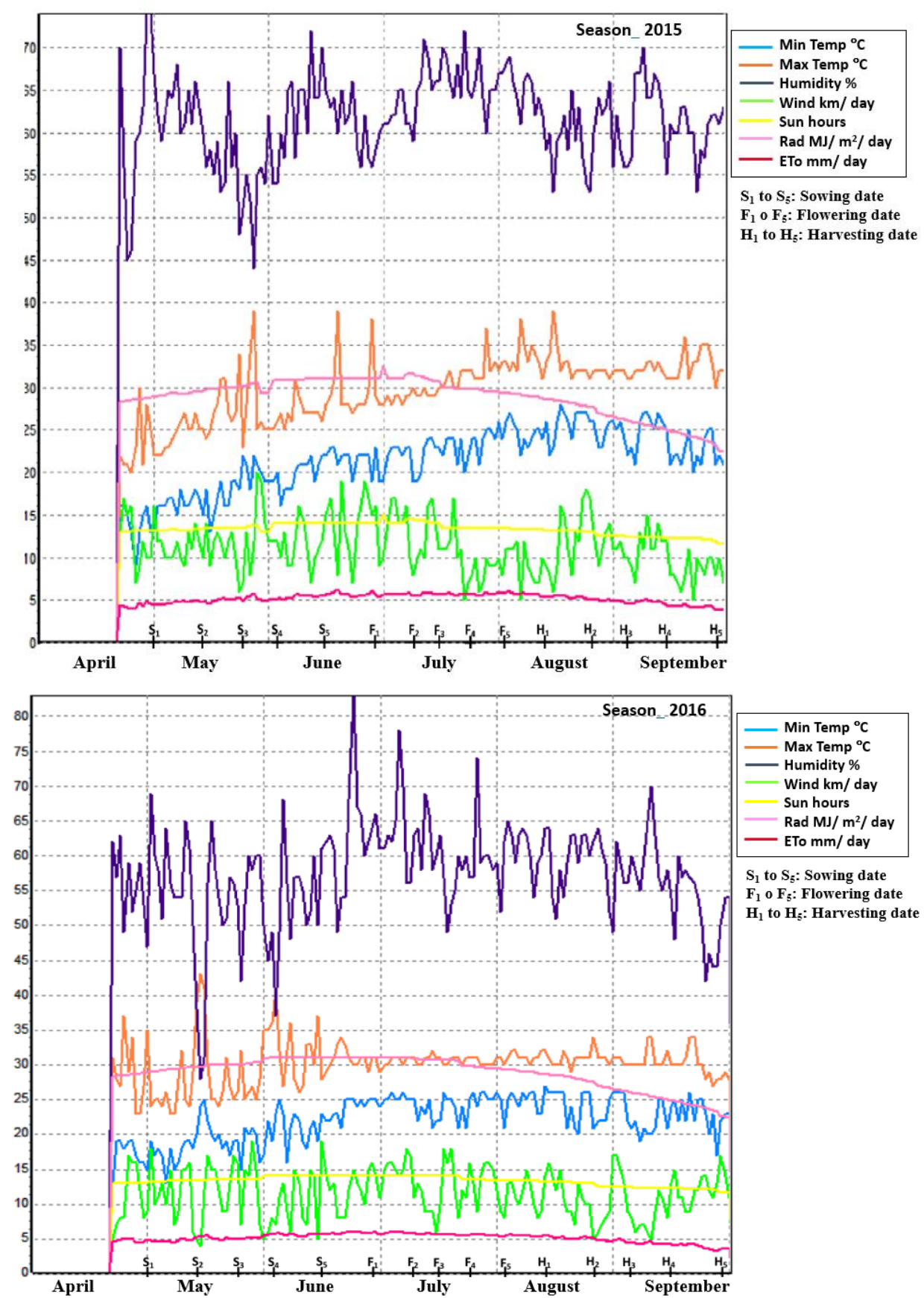

Fig. 1. Meteorological data during the summer seasons of 2015 and 2016 
Table 2: Coded and actual levels of the studied factors in the central composite design

\begin{tabular}{|c|c|c|c|c|c|c|c|c|}
\hline $\begin{array}{l}\text { level } \\
\text { Factors }\end{array}$ & Codec & & Units & $\begin{array}{c}-S \\
\alpha(-2.374)\end{array}$ & $\begin{array}{l}-F \\
(-1)\end{array}$ & $\begin{array}{c}\text { Central } \\
\text { point }(0)\end{array}$ & $\begin{array}{c}+\mathrm{F} \\
(+1)\end{array}$ & $\begin{array}{c}+\mathrm{S} \\
\alpha(+2.374)\end{array}$ \\
\hline Irrigation levels & (I) & $\overline{X_{1}}$ & $\mathrm{~m}^{3} / \mathrm{ha}$ & 4879 & 6388 & 7259 & 8130 & 9639 \\
\hline Potassium levels & (K) & $X_{2}$ & $\mathrm{~kg} / \mathrm{ha}$ & 0.0 & 41.4 & 71.4 & 101.4 & 142.8 \\
\hline Phosphorus levels & (P) & $\mathrm{X}_{3}$ & $\mathrm{~kg} / \mathrm{ha}$ & 0.0 & 34.5 & 59.5 & 84.5 & 119 \\
\hline Nitrogen levels & $(\mathrm{N})$ & $\mathrm{X}_{4}$ & $\mathrm{~kg} / \mathrm{ha}$ & 0.0 & 110.9 & 190.4 & 270.4 & 380.8 \\
\hline & (SD) & $\mathrm{X}_{5}$ & & $15 / 6$ & $3 / 6$ & & $13 / 5$ & $1 / 5$ \\
\hline Plant density & (PD) & $\mathrm{X}_{6}$ & plants/ha & 38080 & 54621 & 66640 & 78659 & 95200 \\
\hline
\end{tabular}

S: Star points, F: Factorial points, - - +: minimum and maximum levels, respectively.

\section{Results and Discussion}

3.1. Effect of six main factors on grain yield

The six studied factors explained $57 \%$ of the variation in grain yield (R2 value, Table 3 ). However, the components that showed significant effects were the linear component for plant density $\left(0.48^{*}\right)$, irrigation $\times \mathrm{K}$ level $\left(-0.45^{*}\right)$, and $\mathrm{P} \times \mathrm{N}$ fertilization level $(-0.69 *)$, as shown in Table 3. Hence, the regression equation that explains the relationship between grain yield and significant components will be: $\mathrm{Y}=$ $6.84+0.48$ X6 - 0.45 X1X2 - 0.69 X3X4.

The regression of grain yield on plant density (Fig. 2) showed that the trait increased with increasing plant density/ha in both the linear and quadratic relationships, showing R2 values of 0.77 and 0.88 , respectively. The coefficient of variation (CV\%) for grain yield was $15.8 \%$, indicating intermediate variability for that trait, which indicated that grain yield was affected by the difference in factor levels, and by lesser magnitude by other factors such as environmental conditions. These findings were confirmed by the mean grain yield, where the highest value (8.05 ton/ha) was achieved at high levels of $\mathrm{I}, \mathrm{K}$ and $\mathrm{N}$ fertilization, and plant density, late sowing date, and low levels of P (F27, Table 4). However, at lower plant densities, levels of $\mathrm{N}$ fertilization and irrigation, combined with high $\mathrm{K}$ and $\mathrm{P}$ fertilization levels and late sowing date, gave high grain yields (F13) (8.06 ton/ ha) comparable to those with input levels of F27. 
Table 3: Analysis of variance and regression coefficients ( $\beta$ ) for grain yield (ton/ha) as affected by irrigation (I), potassium $(\mathrm{K})$, phosphorus $(\mathrm{P})$, and nitrogen fertilization $(\mathrm{N})$, sowing date (SD), and plant density (PD) levels and their interactions.

\begin{tabular}{|c|c|c|c|c|}
\hline S.O.V. & & d.f. & M.S. & $\mathrm{B}$ value \\
\hline & $\beta 0$ & & & $6.84 *$ \\
\hline (1) I (L) & $\beta 1$ & 1 & 0.239 & 0.07 \\
\hline $\mathrm{I}(\mathrm{Q})$ & $\beta 11$ & 1 & 0.278 & -0.07 \\
\hline (2) K (L) & $\beta 2$ & 1 & 2.096 & 0.22 \\
\hline $\mathrm{K}(\mathrm{Q})$ & $\beta 22$ & 1 & 0.036 & 0.02 \\
\hline (3) $P(L)$ & $\beta 3$ & 1 & 1.487 & 0.19 \\
\hline$P(Q)$ & $\beta 33$ & 1 & 1.160 & 0.14 \\
\hline (4) N (L) & $\beta 4$ & 1 & 1.720 & 0.20 \\
\hline $\mathrm{N}(\mathrm{Q})$ & $\beta 44$ & 1 & 3.281 & -0.23 \\
\hline (5) SD (L) & $\beta 5$ & 1 & 0.490 & 0.11 \\
\hline $\mathrm{SD}(\mathrm{Q})$ & $\beta 55$ & 1 & 4.546 & -0.27 \\
\hline (6) PD (L) & $\beta 6$ & 1 & $10.020 *$ & $0.48^{*}$ \\
\hline PD (Q) & $\beta 66$ & 1 & 0.651 & -0.10 \\
\hline $\mathrm{I} \times \mathrm{K}(\mathrm{L})$ & $\beta 12$ & 1 & $6.381^{*}$ & $-0.45^{*}$ \\
\hline $\mathrm{I} \times \mathrm{P}(\mathrm{L})$ & $\beta 13$ & 1 & 0.036 & -0.03 \\
\hline $\mathrm{I} \times \mathrm{N}(\mathrm{L})$ & $\beta 14$ & 1 & 2.850 & 0.30 \\
\hline $\mathrm{I} \times \mathrm{SD}(\mathrm{L})$ & $\beta 15$ & 1 & 1.916 & 0.25 \\
\hline $\mathrm{I} \times \mathrm{PD}(\mathrm{L})$ & $\beta 16$ & 1 & 0.079 & -0.05 \\
\hline $\mathrm{K} \times \mathrm{P}(\mathrm{L})$ & $\beta 23$ & 1 & 0.001 & 0.004 \\
\hline $\mathrm{K} \times \mathrm{N}(\mathrm{L})$ & $\beta 24$ & 1 & 0.064 & 0.05 \\
\hline $\mathrm{K} \times \mathrm{SD}(\mathrm{L})$ & $\beta 25$ & 1 & 2.767 & -0.29 \\
\hline $\mathrm{K} \times \mathrm{PD}(\mathrm{L})$ & $\beta 26$ & 1 & 0.355 & 0.11 \\
\hline $\mathrm{P} \times \mathrm{N}(\mathrm{L})$ & $\beta 34$ & 1 & $15.056^{*}$ & $-0.69 *$ \\
\hline $\mathrm{P} \times \mathrm{SD}(\mathrm{L})$ & $\beta 35$ & 1 & 0.004 & -0.01 \\
\hline $\mathrm{P} \times \mathrm{PD}(\mathrm{L})$ & $\beta 36$ & 1 & 0.077 & -0.05 \\
\hline $\mathrm{N} \times \mathrm{SD}(\mathrm{L})$ & $\beta 45$ & 1 & 0.114 & 0.06 \\
\hline $\mathrm{N} \times \mathrm{PD}(\mathrm{L})$ & $\beta 46$ & 1 & 0.236 & -0.09 \\
\hline $\mathrm{SD} \times \mathrm{PD}(\mathrm{L})$ & $\beta 56$ & 1 & 0.254 & 0.09 \\
\hline Lack of Fit & & 17 & 1.805 & \\
\hline Pure Error & & 11 & 1.038 & \\
\hline Total SS & & 55 & & \\
\hline $\mathrm{R}^{2}$ & & & & 0.57 \\
\hline
\end{tabular}

Linear component (L) and Quadratic component (Q).

*: significant at 0.05 probability level.
Table 4: Means of grain yield combined over the two seasons, as affected by irrigation (I), potassium $(\mathrm{K})$, phosphorus $(\mathrm{P})$, and nitrogen fertilization $(\mathrm{N})$, sowing date (SD), and plant density (PD) levels

\begin{tabular}{|c|c|c|c|c|c|c|c|}
\hline & \multicolumn{6}{|c|}{ Levels } & \multirow{2}{*}{$\begin{array}{c}\text { Grain yield } \\
\text { (ton/ha) }\end{array}$} \\
\hline Trt's & I & $\mathrm{K}$ & $\mathrm{P}$ & $\mathrm{N}$ & SD & PD & \\
\hline $\mathrm{C}_{1-12}$ & 0 & 0 & 0 & 0 & 0 & 0 & 6.78 \\
\hline$S_{1}$ & - & 0 & 0 & 0 & 0 & 0 & 7.72 \\
\hline $\mathrm{S}_{2}$ & + & 0 & 0 & 0 & 0 & 0 & 7.10 \\
\hline $\mathrm{S}_{3}$ & 0 & - & 0 & 0 & 0 & 0 & 6.79 \\
\hline $\mathrm{S}_{4}$ & 0 & + & 0 & 0 & 0 & 0 & 9.06 \\
\hline $\mathrm{S}_{5}$ & 0 & 0 & - & 0 & 0 & 0 & 7.51 \\
\hline $\mathrm{S}_{6}$ & 0 & 0 & + & 0 & 0 & 0 & 9.61 \\
\hline$S_{7}$ & 0 & 0 & 0 & - & 0 & 0 & 5.51 \\
\hline $\mathrm{S}_{8}$ & 0 & 0 & 0 & + & 0 & 0 & 7.47 \\
\hline$S_{9}$ & 0 & 0 & 0 & 0 & - & 0 & 6.21 \\
\hline$S_{10}$ & 0 & 0 & 0 & 0 & + & 0 & 6.31 \\
\hline$S_{11}$ & 0 & 0 & 0 & 0 & 0 & - & 5.41 \\
\hline$S_{12}$ & 0 & 0 & 0 & 0 & 0 & + & 9.01 \\
\hline $\mathrm{F}_{1}$ & -1 & -1 & -1 & -1 & -1 & -1 & 3.96 \\
\hline $\mathrm{F}_{2}$ & -1 & -1 & -1 & -1 & 1 & 1 & 6.24 \\
\hline $\mathrm{F}_{3}$ & -1 & -1 & -1 & 1 & -1 & 1 & 5.37 \\
\hline $\mathrm{F}_{4}$ & -1 & -1 & -1 & 1 & 1 & -1 & 4.80 \\
\hline $\mathrm{F}_{5}$ & -1 & -1 & 1 & -1 & -1 & 1 & 6.90 \\
\hline $\mathrm{F}_{6}$ & -1 & -1 & 1 & -1 & 1 & -1 & 4.98 \\
\hline $\mathrm{F}_{7}$ & -1 & -1 & 1 & 1 & -1 & -1 & 4.28 \\
\hline $\mathrm{F}_{8}$ & -1 & -1 & 1 & 1 & 1 & 1 & 5.65 \\
\hline$F_{9}$ & -1 & 1 & -1 & -1 & -1 & 1 & 5.93 \\
\hline$F_{10}$ & -1 & 1 & -1 & -1 & 1 & -1 & 4.61 \\
\hline $\mathrm{F}_{11}$ & -1 & 1 & -1 & 1 & -1 & -1 & 7.67 \\
\hline$F_{12}$ & -1 & 1 & -1 & 1 & 1 & 1 & 7.18 \\
\hline$F_{13}$ & -1 & 1 & 1 & -1 & -1 & -1 & 8.06 \\
\hline $\mathrm{F}_{14}$ & -1 & 1 & 1 & -1 & 1 & 1 & 7.50 \\
\hline$F_{15}$ & -1 & 1 & 1 & 1 & -1 & 1 & 5.48 \\
\hline$F_{16}$ & -1 & 1 & 1 & 1 & 1 & -1 & 4.96 \\
\hline $\mathrm{F}_{17}$ & 1 & -1 & -1 & -1 & -1 & 1 & 4.92 \\
\hline $\mathrm{F}_{18}$ & 1 & -1 & -1 & -1 & 1 & -1 & 6.44 \\
\hline $\mathrm{F}_{19}$ & 1 & -1 & -1 & 1 & -1 & -1 & 6.68 \\
\hline $\mathrm{F}_{20}$ & 1 & -1 & -1 & 1 & 1 & 1 & 7.79 \\
\hline $\mathrm{F}_{21}$ & 1 & -1 & 1 & -1 & -1 & -1 & 5.97 \\
\hline $\mathrm{F}_{22}$ & 1 & -1 & 1 & -1 & 1 & 1 & 6.88 \\
\hline $\mathrm{F}_{23}$ & 1 & -1 & 1 & 1 & -1 & 1 & 5.40 \\
\hline $\mathrm{F}_{24}$ & 1 & -1 & 1 & 1 & 1 & -1 & 7.59 \\
\hline $\mathrm{F}_{25}$ & 1 & 1 & -1 & -1 & -1 & -1 & 3.44 \\
\hline $\mathrm{F}_{26}$ & 1 & 1 & -1 & -1 & 1 & 1 & 5.18 \\
\hline $\mathrm{F}_{27}$ & 1 & 1 & -1 & 1 & -1 & 1 & 8.05 \\
\hline$F_{28}$ & 1 & 1 & -1 & 1 & 1 & -1 & 6.14 \\
\hline $\mathrm{F}_{29}$ & 1 & 1 & 1 & -1 & -1 & 1 & 7.17 \\
\hline $\mathrm{F}_{30}$ & 1 & 1 & 1 & -1 & 1 & -1 & 5.75 \\
\hline $\mathrm{F}_{31}$ & 1 & 1 & 1 & 1 & -1 & -1 & 4.45 \\
\hline $\mathrm{F}_{32}$ & 1 & 1 & 1 & 1 & 1 & 1 & 6.41 \\
\hline
\end{tabular}




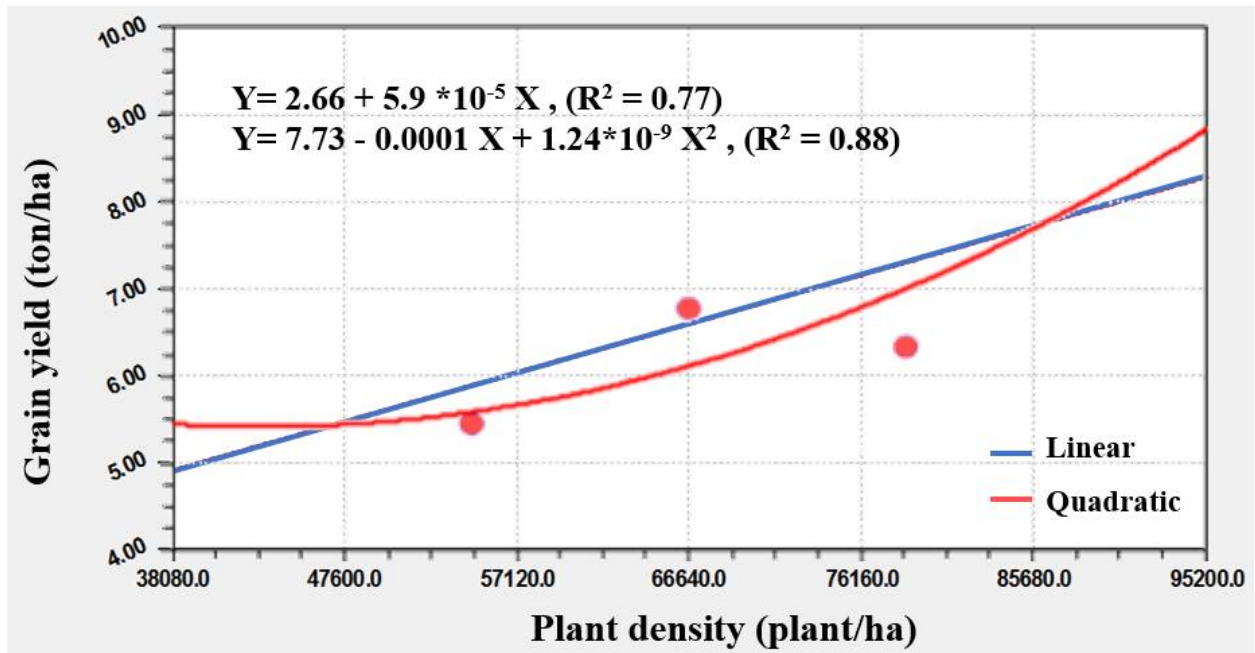

Fig. 2. Effect of plant density on grain yield

The interaction between irrigation and $\mathrm{K}$ fertilization was significant and had a negative relationship with grain yield. The response surface (Fig. 3) showed that grain yield increased with increasing levels of either factor individually, whereas the combined application of both factors, either at their lowest or highest levels, gave lower values than application of the highest levels of individual factors.

Also, the relationship between the $\mathrm{P}$ and $\mathrm{N}$ fertilization interaction and grain yield was significant and negative. The response surface (Fig. 4), showed that grain yield increased when $\mathrm{P}$ and $\mathrm{N}$ fertilization levels increased independently. However, application of both macronutrients in combination gave lower grain yield values relative to application of independent macronutrients.

Grain yield is the ultimate goal for variety improvement and productivity inputs. The main task for agronomists is to determine the optimal combinations of inputs to realize the yield potential of a maize variety, taking into consideration the interaction between input factors. The results obtained from the present study, considering each factor alone, revealed that high grain yields were realized with sowing from May 24 to June 3 with application of high irrigation, $\mathrm{N}$ and $\mathrm{K}$ levels, and plant density. Grain yield increased with increasing plant density, up to 95,200 plants/ha. That may be explained by the growing conditions of the maize in this study where maize was grown under irrigation scheduling to ensure that no water deficit was encountered during the key growth stages of the plant.

Higher irrigation levels, especially under Mediterranean conditions where incidence of drought can be expected, increased grain yield and its components (Nejad et al., 2010; Dahmardeh, 2011 and Zare et al., 2014). Asharf et al. (2016). Wang et al. (2017) reported similar results and added that increased $\mathrm{N}$ fertilization levels with increasing irrigation levels enhanced grain yield and its components. Concerning application of macronutrients, Nejad et al. (2010) found that higher K levels (up to 150 $\mathrm{K}_{2} \mathrm{O} / \mathrm{ha}$ ) increased grain yield, while Hussain et al. (2007) reported that increasing both $\mathrm{K}$ and $\mathrm{P}$ fertilization levels up to (60-90 kg/ha for each) gave the highest grain yield. Moreover, Martineau et al. (2017) found that increasing irrigation with increasing $\mathrm{K}$ fertilization levels gave higher grain yield and yield components. 
In the present study, sowing at May 24 to June 3 gave the highest grain yield (Table 4), while sowing at earlier or later dates resulted in reduction of grain yield. Under growing conditions in Egypt, earlier sowing will subject maize plants to higher infestation by borers (Ostrinia spp.). The same condition applies for later sowing dates, in addition to higher temperatures, which affect pollen grain viability and fertilization, thus reducing grain setting and, finally, grain yield. Existing literature shows contradictory results where Jaliya et al. (2008) and Dahmardeh and Dahmardeh (2010) found that a later sowing date gave higher grain yield and yield components, whereas Rah Khosravani et al. (2017) found that earlier sowing dates resulted in superior grain yield and yield components. This may be explained by differing environmental conditions and possibly the different maize varieties used and their responses to the prevailing environment.

Most of the literature suggests that intermediate plant density (around 66,000 plants/ha) results in higher biological yield,

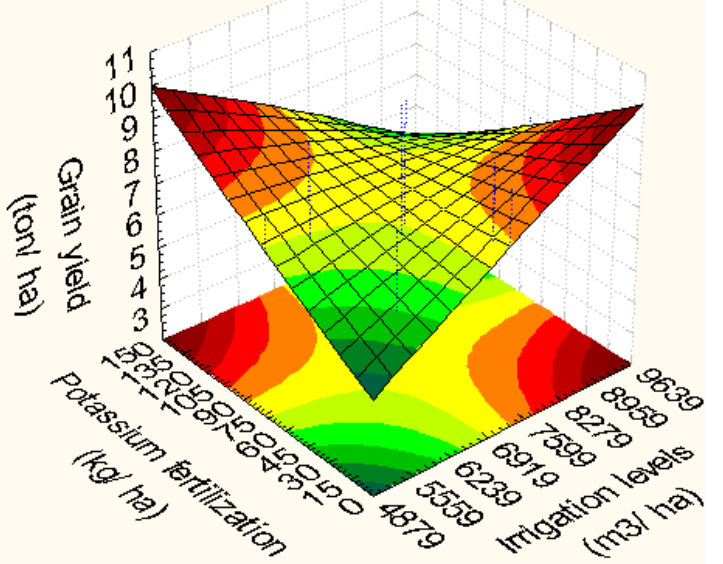

Fig. 3. Response surface for grain yield as affected by irrigation levels and potassium fertilization at the central levels of phosphorus and nitrogen fertilization, plant density, and sowing date.

\subsection{Simulation of irrigation scheduling}

grain yield, and yield components (Turgut et al., 2005; Singh and Singh, 2006 and Ramu and Reddy, 2007). Zakir et al. (2017) found that the same plant density with application of $300 \mathrm{~kg} \mathrm{~N} / \mathrm{ha}$ resulted in the highest grain yield.

The negative relationship between irrigation levels and $\mathrm{K}$ fertilization levels could be explained by the high solubility of $\mathrm{K}$ fertilizer (potassium sulfate), which, in the case of increasing irrigation levels, would lead to increased leaching of the fertilizer from soil, lowering its use efficiency and consequently reducing grain yield.

Concerning the negative $\mathrm{P} \times \mathrm{N}$ interaction, the response surface (Fig. 4) showed that grain yield progressively increased with increasing levels of both macronutrients up to central levels of each. However, further increases in both or either macronutrient(s) reduced grain yields. Onasanya et al. (2009) reported similar findings and stated that increasing $\mathrm{P}$ levels might cause nutrient imbalance and consequently yield depression in maize.

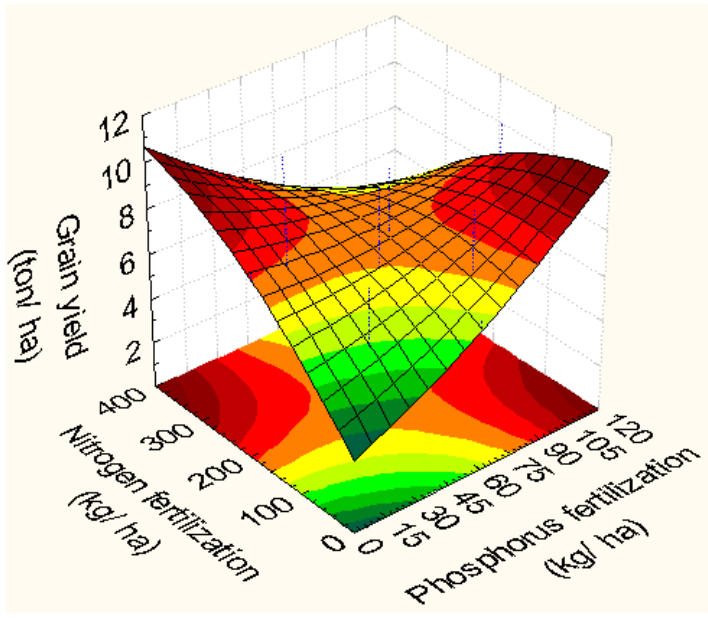

Fig. 4. Response surface for grain yield as affected by phosphorus and nitrogen fertilization levels at the central levels of irrigation, potassium fertilization, plant density, and sowing date.

Irrigation is a major agricultural input for crops, since it determines the germination, 
establishment, growth, and yield of crop plants. Proper application and scheduling of irrigation water, taking into consideration soil and climatic conditions, will affect maize productivity. This study revealed that surface irrigation performed by farmers decreased water use efficiency (WUE) to application of irrigation water in an amount greater than plant requirement, resulting in losses of water to deep percolation. This may be accompanied by a loss in applied nutrients and delay in the transition of plants from the vegetative to reproductive growth stage.

The CROPWAT model display basically incorporates controls, creating a water balance in the soil that enables creation of characteristic irrigation schedules to improve water consumption, assess irrigation schedules and their related yield water profitability, and create optimal water plans under confined water supply conditions (Swennenhuis, 2009 and ElShafei et al., 2015).

Scheduled irrigation levels in this study (Table 5), which ranged from $4879 \mathrm{~m}^{3} /$ ha (S) to $9639 \mathrm{~m}^{3} / \mathrm{ha}(+\mathrm{S})$ every 12 days (9 irrigations), were higher than actual crop use, which ranged from $4070 \mathrm{~m}^{3} / \mathrm{ha}(+\mathrm{F})$ to $4311.3 \mathrm{~m}^{3} / \mathrm{ha}(\mathrm{C})$. That resulted in irrigation water losses ranging from 680 to $5439 \mathrm{~m}^{3} / \mathrm{ha}$ and a decrease in WUE and efficiency of irrigation scheduling (EIS) in the range from 41.3 to $54.1 \%$. According to the CROPWAT model, a slight decrease in grain yield $(1.1 \%)$ was calculated with the lowest irrigation level $(-S)$ due to water stress conditions at the end of the growing season (Fig. 5 a). Actually, at the lowest irrigation level $(-S)$, there was an increase in grain yield of $13.86 \%$ relative to the central value (C) (Table 4). This was attributed to the difference between the actual and assumed value of critical depletion of this maize variety. However, several researchers have reported decreases in maize grain yield with water deficit (stress) relative to incidence of stress (stage of growth) and intensity of stress (Farré and Faci, 2009; Nejad et al., 2010; Ashraf et al., 2016 and Wang et al., 2017).

In an attempt to decrease water loss and increase WUE, using the CROPWAT module, we rescheduled the lowest level of irrigation (-S) at 15-day intervals (Fig. 5 b). Although there were deep percolation losses at five irrigation supplies (Fig. 5 a), these were necessary for good distribution of water and fertilizer application for field surface irrigation. The resulting schedule (Table 5) indicates an increase in the efficiency of irrigation scheduling when compared with that at 12-day intervals (63.8 vs. $54.1 \%$ ), elimination of stress at end of season (Fig 5 b), and no loss in grain yield (Table 5). The distribution of irrigation water according to each interval indicated a high similarity between the irrigation scheduling at both intervals, which allows flexibility in the application of irrigation water at different intervals according to irrigation rotations in the region. The results in Table 5 and Figs. 5 b and 5 c, clearly showed that application of $4879 \mathrm{~m}^{3} /$ ha at $15-$ day intervals was more efficient than the generally applied level of irrigation $(\mathrm{C}, 7259$ $\mathrm{m}^{3} / \mathrm{ha}$ ) at 12-day intervals (EIS 63.8 vs $48.8 \%$ ), without any reduction in grain yield. Several researchers have reported that rescheduling of irrigation water with decreasing amounts of applied water may give higher, or at least similar, grain yield in cereals relative to higher levels of applied irrigation water (Zhang and Oweis, 1999; Kharrou et al., 2011 and El-Shafei et al., 2015). 
Table 5: CROPWAT module for actual crop use, irrigation losses, efficiency of irrigation scheduling, and reduction in yield for applied and predicted irrigation levels.

\begin{tabular}{lccccc}
\hline \multicolumn{6}{l}{ With 12-days interval: } \\
$\begin{array}{l}\text { Irrigation levels } \\
\left(\mathrm{m}^{3} / \mathrm{ha}\right)\end{array}$ & $\begin{array}{c}\text { Total net } \\
\text { irrigation }\end{array}$ & $\begin{array}{c}\text { Actual crop } \\
\text { use }\end{array}$ & $\begin{array}{c}\text { Irrigation } \\
\text { losses }\end{array}$ & EIS $^{*}$ & Yield reduction $(\%)$ \\
\hline $4879(-\mathrm{S})$ & 4879 & 4199 & 680 & 54.1 & 1.1 \\
$6388(-\mathrm{F})$ & 6388 & 4072.3 & 2315.7 & 52.7 & 0.0 \\
$7259(\mathrm{C})$ & 7259 & 4311.3 & 2947.7 & 48.8 & 0.0 \\
$8130(+\mathrm{F})$ & 8130 & 4070 & 4060 & 46.5 & 0.0 \\
$9639(+\mathrm{S})$ & 9639 & 4200 & 5439 & 41.3 & 0.0 \\
\hline With 15 -days interval: & & & & 63.8 & 0.0 \\
\hline $4879(-\mathrm{S})$ & 4879 & 4189 & 690 & & \\
\hline
\end{tabular}

*EIS: Efficiency of irrigation schedule. 
(a)

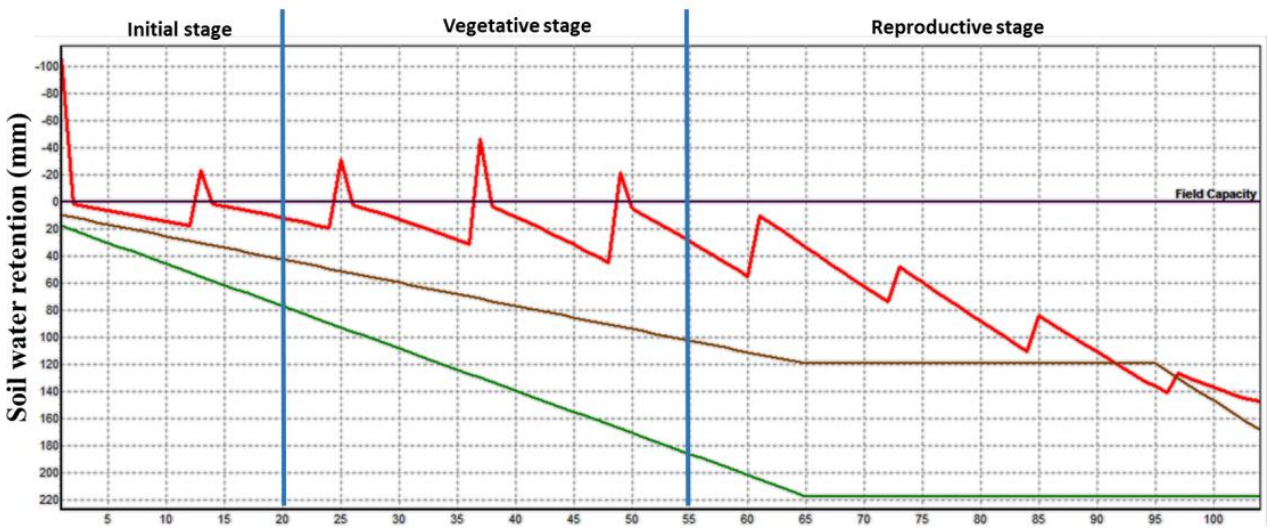

(b)

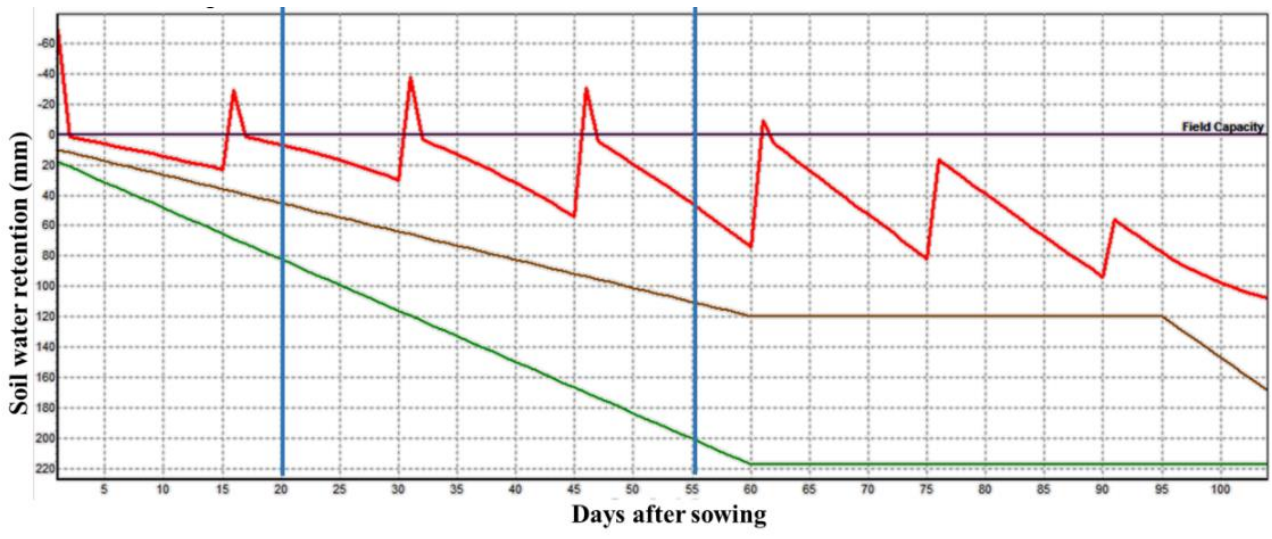

— Depletion — Readily available water (RAW) - Total available water (TAW)

(c)

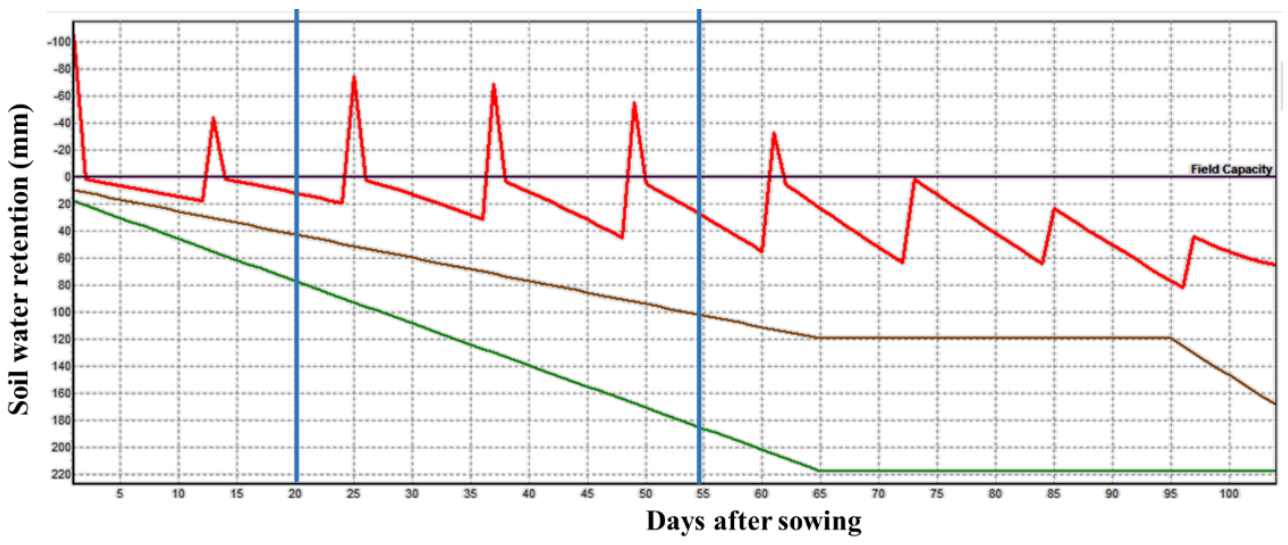

— Depletion — Readily available water (RAW) — Total available water (TAW)

Fig. 5: Soil water balance during the growth season for the May 24; a: sowing date at 4879 $\mathrm{m}^{3} /$ ha for 12 , b: 15 -day intervals and c: sowing date at $7259 \mathrm{~m}^{3} /$ ha for 12 -day intervals.

\section{Conclusion}

The irrigation method presently used for maize production (surface irrigation) leads to huge losses in irrigation water and water use efficiency. The proposed level of 5700 $\mathrm{m}^{3} /$ ha at 12 - or 15 -day intervals overcame those disadvantages and decreased amount of applied water by $21 \%$. The results also indicated a quadratic response of the studied characteristics to levels of applied 
macronutrients and interaction between them. Application of high levels $(+F)$ of $N$ and $\mathrm{K}$ but low levels (-F) of $\mathrm{P}$ (thus saving $42 \%$ of applied $\mathrm{P}$ ) is recommended. The data also suggests that to obtain high grain yield, sowing on the 20 to 30 May with a plant density of 65,000 plants/ha will result in high yield potential for the maize single hybrid Giza 186, in Mediterranean Regions under irrigated conditions.

\section{References}

Abuzar, M.R., Sadozai, G.U., Baloch, M.S., Baloch, A.A., Shah, I.H., Javaid, T. \& Hussain, N. (2011). Effect of plant population densities on yield of maize. Animal \& Plant Sci. J., 21(4), 692-695.

Ali, N. \& Anjum, M.M. (2017). Effect of different nitrogen rates on growth, yield and quality of maize. Middle East J. of Agric. Res., 6(1), 107-112.

Amanullah, M.Z. \& Khalil, S.K. (2010). Timing and rate of phosphorus application influence maize phenology, yield and profitability in Northwest Pakistan. Int. J. Plant Prod., 4(4), 281-292.

Ashraf, U., Salim, M.N., Sher, A., Sabir, S.R., Khan, A., Pan, S. \& Tang, X. (2016). Maize growth, yield formation and water-nitrogen usage in response to varied irrigation and nitrogen supply under semi-arid climate. Turk J. Field Crops, 21(1),87-95.

Box, G.E.P. \& Wilson, K.B. (1951). On the Experimental Attainment of Optimum Conditions. Royal Statistical Society J., Series B. 13 (1): 1-45.

Cochran, W.G. and G.M. Cox (1957). Experimental Designs. John Wiley \& Sons, INC.N.Y., USA.

Dahmardeh, M. (2011). Economical and biological yield of corn (Zea mays
L.) as affected by nitrogen fertilization under different irrigation interstices. J. Food, Agric. and Environ., 9: 472-474.

Dahmardeh, M. \& Dahmardeh, M. (2010). The effect of sowing date and some growth physiological indices on grain yield in three maize hybrids in Southeastern Iran. Asian J. Plant Sci. 9, 432-436.

El-Shafei, A., Allam, K. \& Hamad, T. (2015). Simulation and field verification of water management strategies and wheat crop production. The $20^{\text {th }}$ Annual Conference of Misr. Soc. of Agric. Eng., 12 December 2015. Agric. Eng. and Country Challenges, 427-458.

Farré, I. \& Faci, J.M. (2009). Deficit irrigation in maize for reducing agricultural water use in a Mediterranean environment. Agric. Water Manag., 96: 383-394.

Hammad, H.M., Ahmad, A. Wajid, A., Nasim, W. \& Akhter, J. (2011). Maize response to time and rate of nitrogen application. Pak. J. Bot., 43(4): 1935-1942.

Hammad, H.M., Ahmad, A., Azhar, F., Khaliq, T., Wajid, A., Nasim, W. \& Farhad, W. (2012). Optimizing water and nitrogen requirement in maize (Zea mays L.) under semi arid conditions of Pakistan. Pak. J. Bot., 43(6): 2919-2923.

Hartley, H.O. (1950). The maximum F-ratio as a short-cut test for heterogeneity of variance. Biometrika 37, 3/4: 308312.

Hussain, N., Khan, A.Z. \& Akbar, H. (2007). Response of maize varieties to phosphorus and potassium levels. Sarhad J. Agric., 23(4): 881-887.

Hyams, D. (2005). Curve Expert Version 1.37. A comprehensive curve fitting package for Windows. 
Jaliya, M.M., Falaki, A.M., Mahmud, M. \& Sani, Y.A. (2008). Effect of sowing date and NPK fertilizer rate on yield and yield components of quality protein maize (Zea mays L.). ARPN J. Agric. and Biol. Sci. 3(2): 23-29.

Kharrou M.H., Er-Raki, S, Chehbouni, A. \& Duchemin, B. (2011). Water use efficiency and yield of winter wheat under different irrigation regimes in a semi-arid region. Agric. Sci., 2 (3): 273-282.

Martineau, E., Domec, J.C., Bosc, A. \& Denoroy, P. (2017). The effects of potassium nutrition on water use in field-grown maize (Zea mays L.). Env. and Exp. Bot. J., 134: 62-71.

Nejad, S.D., Nejad, T.S. \& Lack, S. (2010). Study the effect of drought stress and different levels of potassium fertilizer on $\mathrm{K}^{+}$accumulation in corn. Nat. and Sci. J., 8(5): 23-27.

Onasanya, R.O., Aiyelari, O.P., Onasanya, A., Oikeh, S., Nwilene, F.E. \& Oyelakin, O.O. (2009). Growth and yield response of maize (Zea mays L.) to different rates of nitrogen and phosphorus fertilizers in Southern Nigeria. World J. Agric. Sci., 5 (4): 400-407.

Peterson, G.R. (1985). Design and Analysis of Experiments. Marcel Dekker, Inc. New York. pp. 253-301.

Rah Khosravani, A.T., Mansourifar, C., Modarres Sanavy, S.A.M, Asilan, K.S. \& Keshavarz, H. (2017). Effects of sowing date on physiological characteristics, yield and yield components for different maize (Zea mays L.) hybrids. Not. Sci. Biol., 9: 143-147.

Ramu, Y.R. \& Reddy, D.S. (2007). Yield, nutrient uptake and economics of hybrid maize as influenced by plant stand, levels and time of nitrogen application. Crop Res., 33(1-3): 4145.

Singh, D. \& Singh, S.M. (2006). Response of early maturing maize (Zea mays) hybrids to applied nutrients and plant densities under agro-climatic conditions of Udaipur in Rajasthan. Indian J. Agron., 76(6): 372-374.

StatSoft, I. (2012). STATISTICA (data analysis software system), version 7 . 2004. Tulsa, USA, 150.

Swennenhuis, J. (2009). CROPWAT Version 8.0. Water Resources Development and Management Service, FAO, Rome, Italy. http://www.fao.org/landwater/databases-andsoftware/cropwat/en/

Turgut, I., Duman, A., Bilgili, U. \& Acikgoz, E. (2005). Alternate row spacing and plant density effects on forage and dry matter yield of corn hybrids (Zea mays L.). J. Agron. Crop Sci., 191: 146-151.

Wang, Y., Janz, B., Engedal, T. \& Neergaard, A. (2017). Effect of irrigation regimes and nitrogen rates on water use efficiency and nitrogen uptake in maize. Agric. Water Manag., 179: 271-276.

Wang, Z., Lia, J. \& Lia, Y. (2014). Effects of drip system uniformity and nitrogen application rate on yield and nitrogen balance of spring maize in the North China Plain. Field Crops Res., 159: 10-20.

Zakir, U.J., Ali, S., Khan, M.A., Hussain, Z., Ullah, I. \& Ullah, K. (2017). Impact of fertilizer and planting density on weeds population in maize crop. Pak. J. Weed Sci. Res., 23(1): 127132.

Zare, K., Vazin, F. \& Hassanzadehdeloel, M. (2014). Effect of potassium and iron on yield of corn (Zea mays L.) 
in drought stress. Cercetări Agronomice J., 1: 39-47.

Zhang, H. \& Oweis, T. (1999). Water-yield relations and optimal irrigation scheduling of wheat in the Mediterranean region. Agric. Water Manag., 38: 195-211.

Zhang, X., Huang, G. \& Zhao, Q. (2014). Differences in maize physiological characteristics, nitrogen accumulation, and yield under different cropping pattern and nitrogen levels. Chilean J. Agric. Res., 74(3): 326-332.

Zhihui, W., Jianbo, S., Blackwell, M., Haigang, L., Bingqiang, Z. \& Huimin, Y. (2016). Combined applications of nitrogen and phosphorus fertilizers with manure increase maize yield and nutrient uptake via stimulating root growth in a long-term experiment. Pedosphere, 26(1): 62-73.

\section{الملخص العربى}

تم تقييم هجين الذرة الثامية الفردى جيزة 168 فى موسمى صيف 2015 و2016 لصفة محصول الحبوب باستخدام التصميم المركب المركزى لستة عوامل و هى: معدلات كل من الرى السطحى (I)، التسميد البوتاسى (K)، التسميد الفوسفاتى

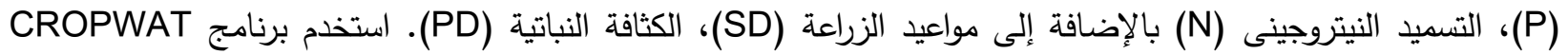
لتقييم معاملات الرى وتطوير جدولة بديلة محسنة لعملية الرى. فسرت العوامل الستة المدروسة 57\% من الاختلافات فى

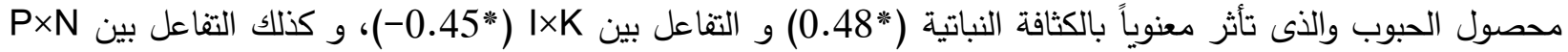
(0.69*-) تم الحصول على أعلى محصول حبوب حوالى ton/ ha 8 من معاملتين، الأولى إشتملت على المستويات العالية من الرى والكثافة النباتية والتسميد النيتروجينى والبوتاسى مع المستويات المنخفضة من الفوسفور والزراعة المتأخرة، والثانية إثتملت على المستويات المنخفضة من الرى والنيتروجين والكثافة النباتية بالإضافة إلى المستويات العالية من البوتاسيوم والفوسفور مع الزراعة المتأخرة.

أظهرت محاكاة جدولة الرى باستخدام CROPWAT أن كمية مياه الرى يمكن خفضها بحوالى 22\% مع زيادة الفترة 100 kg K2O/ha بين الريات إلى 15 يوم بدون نقص فى المحصول. و خلصت النتائج إلى أن إضافة kg N/ha 270 و 34.5 kg P2 $\mathrm{P}_{5} / \mathrm{ha}$ و الزراعة فى الفترة ما بين 30-20 مايو و الكثافة النباتية 65,000 تعطى أعلى محصول حبوب للهجين الفردى جيزة 168. 